\title{
Kebijakan Formulasi Hukum Pidana Dalam Penggunaan Pembuktian Terbalik Dalam Kasus Money Politic Pemilihan Kepala Daerah
}

\author{
Erwin Ubwarin ${ }^{1, *}$ Cindy Agnesia Ratmala ${ }^{2}$ \\ ${ }^{1}$ Fakultas Hukum Pattimura \\ eubwarin@gmail.com ${ }^{1}$; cindyratmala99@gmail.com² \\ *Corespondence Author
}

\begin{abstract}
Abstrak
Kepala Daerah yang tertangkap dalam kasus korupsi merupakan sebuah fenomena di Indonesia, biaya Pemilihan Umum dan Pemilihan Kepala Daerah yang mahal mengakibatkan membutuhkan uang yang banyak, sehingga ditawari oleh pemik modal yang harus diberi proyek setelah calon kepala daerah resmi menjadi kepala daerah, politik uang semacam ini mengancam nilai-nilai demokrasi. Penelitian ini bertujuan menemukan kebijakan formulasi hukum pidana yang dapat diambil dalam hukum acara pidana pemilu untuk menanggulangi politik uang di dalam pemilu. Metode yang dipakai adalah yuridis normatif. Hasil dari penelitian ini adalah Proses menentukan hasil, suatu proses Pemilihan Kepala Daerah dengan pengunaan politik uang sudah terbukti menimbulkan masalah dikemudian hari dengan menghasilkan pemimpin yang melakukan korupsi, karena ia dibiayai oleh pemberi modal, pemberi modal adalah cukong yang akan mengambil proyek pembanguanan suatu daerah, maka diperlukan sebuah kebilakan formulasi hukum pidana untuk menyelesaikan masalah ini. Sarannya adalah memasukan pembuktian terbalik dalam sistem hukum acara tindak pidana Pemilihan Umum dan khususnya Pemilihan Kepala Daerah.
\end{abstract}

Kata Kunci : Kebijakan, Pembuktian Terbalik, Pemilihan, Politik Uang

Naskah dikirim: 21 Desember 2020|Direvisi: 12 Februari 2021|Diterbitkan: 23 Februari 2021

\begin{abstract}
Regional heads who are caught in corruption cases are a phenomenon, high election costs result in a lot of money being required, so that investors are offered a project after the candidate for regional head officially becomes regional head. This kind of money politics threatens democratic values. This study aims to find the formulation of criminal law policies that can be adopted in
\end{abstract}


the criminal law of election procedures to tackle money politics in elections. The method used is normative juridical. The results of this research are the process of determining the results, a process of regional head elections using money politics has been proven to cause problems in the future by producing leaders who commit corruption, because they are financed by capital providers, so a criminal law formulation is needed to solve this problem. The suggestion is to include reverse evidence in the legal system for the criminal act of General Election and especially the Regional Head Election.

Keywords: Policy, Reversed Evidence, Election, Money Politics.

\section{Pendahuluan}

Pemilihan oleh rakyat adalah bentuk dari rakyat memegang kekuasaan itu yang dia percayakan dengan sepenuh hati untuk memilih pemimpinya, namun kadang terjadi pelanggara pemilihan baik Pemilihan Umum dan Pemilihan Kepala Daerah. "Politik dan Uang" dua sahabat yang selalu ada menghiasi Pemilihan Umum di Indonesia, baik sebelum pemilihan umum dilakukan secara langsung dipilih oleh rakyat maupun pemilihan melalui Lembaga Dewan Perwakilan Rakyat, hal ini senada dengan penulis disampaikan oleh Menteri Koordinator Bidang Politik, Hukum, dan Keamanan (Menko Polhukam), Praktik money politic atau politik uang disebut tidak dapat dihindari di ajang pemilihan kepala daerah (Pilkada). Fenomena ini kerap terjadi, baik pemilihan kepala daerah melalui DPRD maupun secara langsung. ${ }^{2}$ Firli Bahuri, mengatakan sejak Tahun 2005 diadakan Pemilihan secara langsung kepala daerah sudah kurang lebih 300 Kepala Daerah yang ditangkap karena Korupsi, beberapa saat setelah bekerja menjadi kepala daerah kemudian ditanggap karena melakukan Tindak Pidana Korupsi, Pilkada seakan menjadi sarana untuk menciptakan sarana baru calon koruptor baru. ${ }^{3}$ Badan Pengawasan Keuangan dan Pembagunan (BPKP) mengatakan sudah 343 kepala daerah yang berperkara hukum baik di Kejaksaan, Kepolisian, maupun Komisi Pemberantasan Korupsi (KPK). Sebagian besar karena tersangkut masalah pengelolaan keuangan daerah. "Data terakhir sampai bulan Desember 2015 tercatat cukup tinggi, Gubernur, Bupati, Walikota adalah 343 orang yang ada masalah hukum baik ditangani oleh Kejaksaan, Polisi, KPK. Data Kementerian Dalam Negeri

1 Corputty, P. (2019). Masa Tenang Kampanye Politik Pada Media Sosial Dan Ketentuan Pemidanaanya. JURNAL BELO, 5(1), 110-122. https://doi.org/10.30598/belovol5issue1page110-122

2 https://www.cnnindonesia.com/nasional/20200905211752-32-543196/mahfud-md-sebut-politik-uangselalu-ada-di-setiap-pilkada. Diakses 19 Januari 2021

3 https://nasional.kompas.com/read/2020/08/07/15133851/kpk-catat-300-kepala-daerah-jadi-tersangkakorupsi-sejak-pilkada-langsung diakses 19 Januari 2021

DOI: https://doi.org/10.30598/belovol6issue2page221-231 
menyebutkan, hingga tahun 2010, ada 206 kepala daerah yang tersangkut kasus hukum. Tahun selanjutnya, Kementerian Dalam Negeri mencatat secara rutin yaitu 40 kepala daerah (2011), 41 kepala daerah (2012), dan 23 kepala daerah (2013), BPKP menemukan penyebab tingginya kepala daerah yaitu :

1. Monopoli kekuasaan

Berdasarkan wawancara dengan beberapa informan tentang monopoli kekuasaan di simpulkan bahwa kepala daerah memiliki kekuasaan yang sangat besar dalam pengelolaan anggaran APBD, perekrutan pejabat daerah, pemberian ijin sumber daya alam, pengadaan barang dan jasa dan pembuatan peraturan kepala daerah, dan adanya dinasti kekuasaan, hal ini menyebabkan kepala daerah melakukan tindak pidana korupsi melalui suap dan gratifikasi

2. Diskresi kebijakan.

Berdasarkan pernyataan dari informan bahwa hak diskresi melekat pada pejabat publik, khususnya kepala daerah, artinya diskresi di lakukan karena tidak semua tercakup dalam peraturan sehingga diperlukan kebijakan untuk memutuskan sesuatu, sehingga apa yang ditarget itu bisa terpenuhi tanpa harus menunggu adanya aturan yang tersedia, masalahnya kemudian diskresi ini dipahami secara sangat luas, padahal diskresi itu sangat terbatas, dia hanya bisa diberi ruangnya ketika tidak ada aturan main dan itu dalam situasi yang sangat mendesak, APBD merupakan dasar pengelolaan keuangan daerah dalam satu tahun anggaran yang merupakan rencana pelaksanaan Pendapatan Daerah dan Belanja Daerah dalam rangka pelaksanaan Desentralisasi dalam tahun anggaran tertentu. Pemungutan penerimaan daerah bertujuan untuk memenuhi target yang ditetapkan dalam APBD.

Demikian pula pengeluaran daerah dan ikatan yang membebani daerah dalam rangka pelaksanaan desentralisasi dilakukan sesuai jumlah dan sasaran yang ditetapkan dalam APBD. Dalam pelaksanaannya kepala daerah sering dihadapkan pada kenyataan untuk membiayai suatu kegiatan yang tidak dianggarkan dalam APBD. Informan 1 menjelaskan adanya situasi dimana seorang kepala daerah mengeluarkan biaya yang tidak ada dalam APBD, oleh sebab itu kepala daerah mencari celah untuk menciptakan pengeluaran fiktif untuk menutupi biaya tersebut sehingga kepala 
daerah cenderung melakukan korupsi untuk kepentingan dinas maupun untuk kepentingan pribadi.

3. Lemahnya Akuntabilitas.

Kolusi Eksekutif dan Legislatif dalam Pembuatan Kebijakan yang Koruptif.

Dalam wawancara dengan Informan menyatakan kondisi pada saat ini adanya kolusi antara kepala daerah dengan DPRD terkait dengan kebijakan yang dibuat oleh kepala daerah misalnya masalah pembuatan perda dan perijinan.termasuk dalam lemahnya akuntabilitas adalah kurang nya transparansi dalam pengelolaan anggaran, pengelolaan asset dan dalam pengadaan barang dan jasa, sehingga menyebabkan kepala daerah melakukan tindak pidana korupsi.

\section{Faktor Lainya}

Beberapa faktor penyebab kepala daerah melakukan korupsi lainnya antara lain karena biaya pemilukada langsung yang mahal, kurangnya kompetensi dalam pengelolaan keuangan daerah, kurang pahamnya peraturan, dan pemahaman terhadap konsep budaya yang salah.

Dari beberapa faktor penyebab korupsi kepala daerah di atas, perlu di lakukan pencegahan dan pengawasan yang efektif yaitu dengan meningkatkan pembinaan terhadap SPIP di pemerintah daerah. BPKP sebagai Pembina SPIP telah melakukan sosialisasi dan pembinaan SPIP, bekerjasama dengan KPK, telah melakukan pencegahan korupsi. BPKP telah melakukan kerjasama dengan aparat penegak hukum dalam pencegahan dan pengawasan tindak pidana korupsi, namun hasilnya belum optimal, sehingga harus di tingkatkan di waktu yang akan datang. ${ }^{4}$

Dari data hasil penelitian di atas ditemukan bahwa salah satu peyebab kepala daerah melakukan korupsi adalah sistem pemilihan kepala daerah yang mahal, kenapa mahal, karena disana ada perputaran aliran uang untuk memenangkan kandidat calon kepala daerah yang maju, dari penelitian ini akan membahas tentang kebijakan formulasi hukum pidana dalam penanggulangan money politic pada Pilkada yang ditunda sampai dengan tahun 2024. Jadi tujuan

4 http://www.bpkp.go.id/puslitbangwas/konten/2674/16.050-Faktor-Faktor-Penyebab-Kepala-DaerahKorupsi, diakses 20 Januari 2021 
penulisan ini untuk menemukan formulasi yang tepat dalam Undang-Undang Pemilihan Kepala Daerah.

Penelitian ini menggunakan metode penelitian hukum normatif, dengan memakai sumber bahan hukum primer yang diambil dari peraturan perundang-undangan, dan bahan hukum sekunder dari buku dan jurnal-jurnal yang berhubungan dengan penulisan. Pendekatan yang dilakukan adalah pendekatan perundang-undangan dan pendekatan konsep, penulisan ini bersifat deskritif analitis. ${ }^{5}$

\section{Pembahasan}

Beberapa penelitian dalam salah satu pertimbangan peralihan mekanisme Pilkada oleh Dewan Perwakilan Rakyat Daerah (DPRD) menjadi Pilkada langsung, melalui DPRD adalah untuk memangkas politik uang (money politics), logikanya calon tidak punya kemampuan untuk membeli suara rakyat yang jumlahnya banyak. Namun fakta menunjukkan bahwa dalam pilkada langsung pun politik uang berlangsung meski dengan ongkos yang makin mahal karena melibatkan pemilih dalam satu daerah pemilihan. ${ }^{6}$ Sebelum masuk kedalam tahap Pilkada secara langsung kepala daerah, calon kepala daerah yang akan maju akan mencari dukungan partai politik atau gabungan partai politik sebagai pengusung bakal calon kepala daerah, dan untuk merebut hati dari para partai politik ini ada yang namanya "mahar politik", mahar politik diberikan kepada partai yang mempunyai kursi di Dewan Perwakilan Rakyat Daerah.

Jetty M Patty, dalam penelitiannya menyebutkan bahwa korupsi dan Pilkada sangat berhubungan erat, jika proses Pikada yang tidak berjalan dengan baik, seperti terlibatnya peserta yang menggunakan politik uang, tepidana korupsi yang kembali lagi menjadi calon, maka berpotensi akan terjadi lagi kesalahan yang sama. ${ }^{7}$ Feri Amsari, Hemi Lavour Febrinandez mengatakan "Uang Mahar" sebagai syarat untuk dapat dicalonkan partai telah merusak tujuan dari Pemilu. Pemerintahan yang dihasilkan cenderung koruptif. Itu sebabnya pencegahan praktik uang mahar dalam Pemilu menjadi sangat penting. Upaya menghentikannya tidak dapat

\footnotetext{
${ }^{5}$ Peter Mahmud Marzui, Penelitian Hukum, (Jakarta: Prenada Media Group), 2005, hal. 93.

${ }^{6}$ Fitriyah, D. F. M. (2013). FENOMENA POLITIK UANG DALAM PILKADA. Politika: Jurnal Ilmu Politik, 3(1), 5-14. DOI : https://doi.org/10.14710/politika.3.1.2012.5-14

7 Patty, J. (2020). Tindak Kekerasan Terhadap Anak di Lingkungan Satuan Pendidikan dan Peranan Keluarga Sebagai Upaya Non-Penal Dalam Pencegahan. JURNAL BELO,5(2), 115-129. DOI : https://doi.org/10.30598/belovol5issue2page115-129
} 
bersandar kepada pemilih dengan menyarankan tidak memilih politisi korup atau yang menggunakan politik uang. Pemilih cenderung permisif. Pelaku korupsi acapkali dimaafkan dalam Pemilu dengan memilih mereka sekali lagi, apalagi politisi yang mempraktikan uang mahar. ${ }^{8}$

Almas Ghaliya Putri Sjafrina, Persoalan politik uang dalam pemilu, khususnya mahar politik dan jual beli suara yang menjadi fokus dalam tulisan ini, mempunyai dampak yang luas. Jangka pendeknya, dua penyakit ini akan merusak momentum sirkulasi elit lima tahunan yang seharusnya menjadi ajang untuk menghadirkan kedaulatan rakyat secara langsung. Baik dalam tahap pencalonan maupun dalam tahap pemungutan suara di TPS. Persoalan transaksional dalam penentuan kandidat Pemilhan Umum yang partai politik usung masih bermunculan. Termasuk, jual beli suara yang juga bersumber dari uang korupsi. ${ }^{9}$ Rusaknya tatanan demokrasi karena uang yang beredar akan berdampak pada produk pemilu itu sendiri, apakah pimpinannya maupun programnya yang sudah terbagi habis baik kepada para penyedia modal yang menadi sponsor utama penyumbang dana, dan para kolega serta keluarga menjadi potret buruk dari proses demokrasi yang berjalan saat ini, maka harus ada regulasi yang dibuat dalam pencegahan jangan sampai oknum-oknum Kepala Daerah yang korup akan muncul lagi.

Menurut Penulis ada beberapa bentuk perbuatan yang dapat dikatagorikan Politik Uang (Money Politic) :

a. Pengunaan Uang untuk mempengaruhi partai pendukung sebagai syarat pemberiaan dukungan

b. Pengunaan Uang untuk mempengaruhi suara pemilih, dengan memberikan bantuan sosial yang didalamnya ada artibut-artibut partai atau pasangan calon yang didukung oleh calon

c. Pengunaan uang untuk mempengaruhi penyelenggara pemilu.

d. Pengunaan uang dalam membeli suara atau bisa disebut dengan serangan fajar.

Politik uang adalah fenomena gunung es, yang diatas hanya kelihatan sedikit, namun dibawahnya sangat besar adanya, yang kita liat di media massa ataupun tindakan penegakan hukum yang

8 Feri Amsari, Hemi Lavour Febrinandez, Menjerakan Pelaku "Uang Mahar" Pemilu Jurnal Antikorupsi INTEGRITAS, 5 (1), 97-110. DOI: https://doi.org/10.32697/integritas.v5i1.412

9 Almas Ghaliya Putri Sjafrina, Dampak Politik Uang Terhadap Mahalnya Biaya Pemenangan Pemilu dan Korupsi Politik Jurnal Antikorupsi INTEGRITAS, 5 (1), 43-53 DOI: https://doi.org/10.32697/integritas.v5i1.389 
dilakukan oleh Badan Pengawas Pemilu (Bawaslu) menurut hasil penelitian penulis masih lemah, karena hal ini berdasarkan temuan bukan laporan masyarakat. Karena ada yang salah dalam rumusan pasal 187A Undang-Undang Republik Indonesia Nomor 10 Tahun 2016 tentang Perubahan Kedua atas Undang-Undang Nomor 1 Tahun 2015 tentang Penetapan Peraturan Pemerintah Penganti Undang Nomor 1 Tahun 2014 tentang Pemilihan Gubernur, Bupati, dan Walikota Menjadi Undang-Undang. Menyebutkan :

Ayat (1)

Setiap orang yang dengan sengaja melakukan perbuatan melawan hukum menjanjikan atau memberikan uang atau materi lainnya sebagai imbalan kepada warga negara Indonesia baik secara langsung ataupun tidak langsung untuk mempengaruhi Pemilih agar tidak menggunakan hak pilih, menggunakan hak pilih dengan cara tertentu sehingga suara menjadi tidak sah, memilih calon tertentu, atau tidak memilih calon tertentu sebagaimana dimaksud pada Pasal 73 ayat (4) dipidana dengan pidana penjara paling singkat 36 (tiga puluh enam) bulan dan paling lama 72 (tujuh puluh dua) bulan dan denda paling sedikit Rp200.000.000,00 (dua ratus juta rupiah) dan paling banyak Rp1.000.000.000,00 (satu milyar rupiah).

Ayat (2)

Pidana yang sama diterapkan kepada pemilih yang dengan sengaja melakukan perbuatan melawan hukum menerima pemberian atau janji sebagaimana dimaksud pada ayat (1).

Kebijakan Formulasi Hukum Pidana tentang formulisasi pasal 187A Undang-Undang 10 Tahun 2016 ini sangat menyulitkan untuk ditegakan kecuali terjadi temuan dari Bawaslu itu sendiri, karena orang yang mengambil uang tersebut dia akan melakukan penyangkalan telah menerima uang dari pihak yang memberikan uang dan ini sulit untuk diusut, karena penerima uang dan pemberi uang posisinya sama, karena keduanya akan dihukum jika memberitahukan telah terjadi politik uang dalam pemilihan kepala daerah. Bawaslu sulit mencari saksi yang mau mengatakan dia telah menerima uang dari peserta pemilu. Maka berbeda dengan Pasal 523 Undang-Undang Nomor 7 Tahun 2017 tentang Pemilihan Umum.

Ayat (1) 
Setiap pelaksana, peserta, dan/atau tim Kampanye Pemilu yang dengan sengaja menjanjikan atau memberikan uang atau materi lainnya sebagai imbalan kepada peserta Kampanye Pemilu secara langsung ataupun tidak langsung sebagaimana dimaksud dalam Pasal 280 ayat (1) huruf j dipidana dengan pidana penjara paling lama 2 (dua) ahun dan denda paling banyak Rp 24.000.000, (dua puluh empat juta rupiah).

Ayat (2)

Setiap pelaksana, peserta, dan/atau tim Kampanye Pemilu yang dengan sengaja pada Masa Tenang menjanjikan atau memberikan imbalan uang atau materi lainnya kepada Pemilih secara langsung ataupun tidak langsung sebagaimana dimaksud dalam Pasal 278 ayat (2) dipidana dengan pidana penjara paling lama 4 (empat) tahun dan denda paling banyak Rp 48.000.000,00 (empat puluh delapan juta rupiah).

Ayat (3)

Setiap orang yang dengan sensaja pada hari pemungutan suara menjanjikan atau memberikan uang atau materi lainnya kepada Pemilih untuk tidak menggunakan hak pilihnya atau memilih Peserta Pemilu tertentu dipidana dengan pidana penjara paling lama 3 (tiga) tahun dan denda paling banyak Rp 36.000.000,00 (tiga puluh enam juta rupiah).

Tahap kebijakan formulasi merupakan tahap yang paling strategis. Pada tahap kebijakan formulasi inilah disusun semua "perencanaan" (planning) penanggulangan kejahatan dengan sistem hukum pidana. Keseluruhan sistem hukum pidana yang dirancang itu, pada intinya mencakup 3 (tiga) masalah pokok dalam hukum pidana, yaitu masalah perumusan tindak pidana (kriminalisasi), pertanggungjawaban pidana, dan aturan pidana dan pemidanaan. Kalau menggunakan istilah Nils Jareborg, yang dirancang itu meliputi keseluruhan struktur sistem hukum pidana ("the structure of the penal system") yang mencakup masalah "kriminalisasi dan pidana yang diancamkan" ("criminalization and threatened punishment"), masalah "pemidanaan ("adjudication of punishment (setencing)"; dan masalah "pelaksanaan pidana" ("execution of punishment”). ${ }^{10}$ Kebijakan penenaganan Pemilihan umum harus dilakukan dengan baik, karena jika salah maka akan hadir pemimpin yang dihasilkan dari pemilu yang curang. ${ }^{11}$

10 Barda Nawawi Arief, 2010, Masalah Penegakan Hukum dan Kebijakan Hukum Pidana Dalam Penanggulangan Kejahatan, Kencana Prenada Media Group, Jakarta, hal 223

11 Sarkol, T. (2020). Strategi Pengawasan Pelanggaran Pidana Pemilu Pada Daerah Kepulauan Maluku. JURNAL BELO, 6(1), 32-47. DOI : https://doi.org/10.30598/belovol6issuelpage32-47 
Dalam penulisan hasil penelitian ini penulis mengajukan sebuah rujukan kebijakan formulasi yang harus dilakukan dengan pengunaan pembuktian terbalik untuk kasus-kasus politik uang baik melibatkan perserta, penyelenggara atau pemilih itu sendiri sehingga orang takut melakukan politik uang dalam demokrasi di Indonesia. Martiman Prodjohamidjojo menyatakan "Perkara berimbang dikatakan lebih tepat sebagai sebanding, dilukiskan sebagai/berupa penghasilan terdakwa ataupun sumber penambahan harta benda terdakwa, sebagai income terdakwa dan perolehan harat benda sebagai output." ${ }^{2}$ Terdakwa tindak pidana pemilu dalam kasus politik uang harus dilacak jumlah hartanya apakah sudah seimbang dengan pendapatan dia, wajar tidak setelah menjadi penyelenggara, atau perserta pemilu atau pemilih yang dalam proses pemilu jumlah kekeayaannya bisa naik dratis.

Prospek kebijakan hukum pidana mencakup persoalan kebijakan hukum pidana yang berlaku pada saat ini (ius constitutum) dan kebijakan hukum pidana untuk masa yang akan datang atau hukum yang dicita-citakan (ius constitutuendum). ${ }^{13}$ Ayu Komang Sari Merta Dewi dan I Gusti Ayu Puspawati mengatakan Sistem pembuktian terbalik adalah salah satu bentuk extraordinary legal instrument yang dibentuk. ${ }^{14}$ Pemasukan rumusan sistem pembuktian terbalik dalam Undang-Undang Pemilu akan menambah perbaikan kualitas pemilu itu sendiri. Kebijakan formulasi hukum pidana dengan memasukan dalam revisi Undang-Udang Nomor 7 Tahun 2017 dan khususnya Undang-Undang tentang Pemilihan Gubernur, Bupati dan Walikota ini perlu untuk membuat efek jera.

\section{Penutup}

Proses menentukan hasil, suatu proses Pemilihan Kepala Daerah dengan pengunaan politik uang sudah terbukti menimbulkan masalah dikemudian hari dengan menghasilkan pemimpin yang melakukan korupsi, karena ia dibiayai oleh pemberi modal, maka diperlukan sebuah kebilakan formulasi hukum pidana untuk menyelesaikan masalah ini. Sarannya adalah

\footnotetext{
12 Martiman Prodjohamidjojo, 2012 Penerapan Pembuktian Terbalik Dalam Delik Korupsi (UU No. 31 Tahun 1999), CV. Mandar Maju, Bandung, hal 98

${ }^{13}$ Ubwarin, E. (2017). KEBIJAKAN FORMULASI HUKUM PIDANA DALAM PENANGGULANGAN TINDAK PIDANA PERJUDIAN MELALUI INTERNET (INTERNET GAMBLING). SASI, 23(1), 73-81. DOI: https://doi.org/10.47268/sasi.v23i1.161.

${ }^{14}$ Sari Merta Dewi, A., \& Puspawati, I. (2013). PENERAPAN SISTEM PEMBUKTIAN TERBALIK DALAM UPAYA PEMBERANTASAN TINDAK PIDANA KORUPSI. Kertha Negara : Journal Ilmu Hukum, hal 3
} 
memasukan pembuktian terbalik dalam sistem hukum acara tindak pidana Pemilihan Umum dan khususnya Pemilihan Kepala Daerah.

\section{Daftar Pustaka}

\section{Jurnal}

[1] Pemilu dan Korupsi Politik Jurnal Antikorupsi INTEGRITAS, 5 (1), 43-53 DOI: https://doi.org/10.32697/integritas.v5i1.389

[2] Corputty, P. (2019). Masa Tenang Kampanye Politik Pada Media Sosial Dan Ketentuan Pemidanaanya. JURNAL BELO, 5(1),

110-122. https://doi.org/10.30598/belovol5issue1page110-122

[3] Fitriyah, D. F. M. (2013). FENOMENA POLITIK UANG DALAM PILKADA. Politika: Jurnal Ilmu Politik, 3(1), 5-14. DOI : https://doi.org/10.14710/politika.3.1.2012.5-14

[4] Feri Amsari, Hemi Lavour Febrinandez, Menjerakan Pelaku "Uang Mahar" Pemilu $\begin{array}{lllll}\text { Jurnal Antikorupsi INTEGRITAS, } 5 & \text { (1), 97-110. DOI: }\end{array}$ https://doi.org/10.32697/integritas.v5i1.412

[5] Patty, J. (2020). Tindak Kekerasan Terhadap Anak di Lingkungan Satuan Pendidikan dan Peranan Keluarga Sebagai Upaya Non-Penal Dalam Pencegahan. JURNAL BELO, 5(2), 115-129. DOI : https://doi.org/10.30598/belovol5issue2page115-129

[6] Martiman Prodjohamidjojo, 2012 Penerapan Pembuktian Terbalik Dalam Delik Korupsi (UU No. 31 Tahun 1999), CV. Mandar Maju, Bandung.

[7] Sarkol, T. (2020). Strategi Pengawasan Pelanggaran Pidana Pemilu Pada Daerah Kepulauan Maluku. JURNAL BELO, 6(1), 32-47. DOI : https://doi.org/10.30598/belovol6issue1page32-47

[8] Sari Merta Dewi, A., \& Puspawati, I. (2013). PENERAPAN SISTEM PEMBUKTIAN TERBALIK DALAM UPAYA PEMBERANTASAN TINDAK PIDANA KORUPSI. Kertha Negara : Journal Ilmu Hukum.

[9] Ubwarin, E. (2017). KEBIJAKAN FORMULASI HUKUM PIDANA DALAM PENANGGULANGAN TINDAK PIDANA PERJUDIAN MELALUI INTERNET (INTERNET GAMBLING). SASI, 23(1), 73-81. https://doi.org/10.47268/sasi.v23i1.161 


\section{Buku}

[10] Peter Mahmud Marzui, 2015, Penelitian Hukum, Prenada Media Group, Jakarta

[11] Barda Nawawi Arief, 2010, Masalah Penegakan Hukum dan Kebijakan Hukum Pidana Dalam Penanggulangan Kejahatan, Kencana Prenada Media Group, Jakarta.

\section{Dan Lain-Lain}

[12] https://www.cnnindonesia.com/nasional/20200905211752-32-543196/mahfud-mdsebut-politik-uang-selalu-ada-di-setiap-pilkada. Diakses 19 Januari 2021

[13] https://nasional.kompas.com/read/2020/08/07/15133851/kpk-catat-300-kepaladaerah-jadi-tersangka-korupsi-sejak-pilkada-langsung diakses 19 Januari 2021

[14] http://www.bpkp.go.id/puslitbangwas/konten/2674/16.050-Faktor-Faktor-PenyebabKepala-Daerah-Korupsi, diakses 20 Januari 2021 